\title{
人文主义地理学对城市空间文本的解读 以《北京文脉》插图为例
}

\author{
周尚意 ${ }^{1}$, 许伟麟 ${ }^{1}$, 李建平 ${ }^{2}$ \\ (1. 北京师范大学地理科学学部, 北京 $100875 ; 2$. 北京市哲学和社会科学规划办公室, 北京 100101)
}

\begin{abstract}
摘 要: 人文主义地理学是地理学的一种认识论, 其特点是我向性、诉诸情感和感悟性。以往的人文主义地理学分 析案例多关注地方感的主体性, 而对认识与被认识的循环过程中的人文主义特点关注不够。本文以《北京文脉》一 书的三幅插图为例, 对比插图者自述和读者(本文作者)的读后感, 分析北京城市空间认识过程中的人性提升。主 要结论有二, 一是在三幅插图的作者和读者的空间认识过程中, 感悟性更重要; 二是插图作者和读者均经历了“文 本一基于文本的感悟一超越文本的提升”的认识循环, 这个过程是人性提升的必然途径。因此, 在每次修改城市规 划时, 人们一定要回答人性有何提升。
\end{abstract}

关 键 词: 人文主义地理学; 北京城市; 空间感知-认知

\section{1 引言}

北京联合大学于 2017 年 5 月举办了一个“城市 文化空间感知”的学术会议。参会的学者从不同角 度探讨了如何感知文化空间。与会学者以自媒体 文本、诗歌词汇、人们出行轨迹等作为研究对象, 并 将之与空间做匹配, 作为人们对空间的感知结果。 早在 2008 年文化地理学的沙龙上, 李蕾蕾(2009)就 提出: 文化地理学要超越西方, 首先要了解“语言转 向”, 这是“文本转向” 的基础。可喜的是, 这些年来 有许多学者开始从各类“文本” 人手, 分析城市空间 感知或 “地方(感)”。例如, 安宁等(2017)研究了小 说《炸裂志》的作者对城市化过程中空间变迁的感 知; 尹铎等(2016)研究西方主流媒体对中国城市新 区的消极感知。但是尚缺少从语言转向人手的研 究。本文选择的手绘图也许是一种“语言”。

地理初学者会问, 为什么要讨论城市空间感 知? 作为人文主义地理学的拥歪, 我们给出的答案
是一一为了探究人们感知空间的过程是否有助人 们提升人性。现在的问题是, 许多研究并没有实现 这一目标, 而仅是停留在发掘感知结果的水平上。 因此, 本文探讨如何用人文主义地理学的方法, 分 析已经表达出来的城市感知结果一一本关于北 京文脉的书(李建平, 2017), 以及读者阅读该书的再 感悟结果, 说明城市空间感知与人性提升的关系。

\section{2 人文主义地理学认识论下的城市空 间感知研究}

\section{1 人文主义地理学认识论特点}

人文主义地理学在认识世界时有 3 个特点(周 尚意等, 2005),这是笔者基于对人文主义地理学奠 基人段义孚著作的理解而总结出来的。Gregory (2000)对人文主义地理学也有一个精要的定义。但 是多数人认为, 要将人文主义地理学作为一个学科 来理解, 还得看 Tuan(1976)最原初的那篇经典的文

收稿日期: 2017-08; 修订日期: 2017-09。

基金项目: 国家自然科学基金项目(41771148); 中国西南地缘环境与边疆发展协同创新中心项目[Foundation: National Natural Science Foundation of China, No.41771148; Collaborative Innovation Center for Geopolitical Setting of Southwest China and Borderland Development]。

作者简介: 周尚意(1960-), 女, 广西罗城人, 教授, 博士生导师, 主要从事社会文化地理学研究, E-mail: twizsy@163.com。 
章(Allen, 2017)。人文主义认识论的 3 个特点分别 为:第一, “我向”思维。即人们对客体的认识基础 都是来自认识主体 “我” 的感知一认知基础。身体 是人们感知的出发点 (莫里斯・梅洛-庞蒂, 2001), 如 薄伽丘笔下的少年从人身体的本性上就是喜欢“绿 我”; 第二, 诉诸情感。人们认识空间客体是包含情 感的。由于个人经历不同, 不同的人对同一空间的 情感不同, 因此认识的结果也不同, 如俗语“金窝银 窝不如自家的狗窝”; 第三, 感悟性。感悟是一种基 于经验且超越经验的人类思维, 如看到世间不平 等, 不是麻木不仁, 而是感悟出平等、正义世界的样 貌, 并喊出 “王侯将相宁有种乎”。上述 3 个特点都 闪耀着人性之光芒。因此, 运用人文主义地理学的 视角研究城市空间感知, 就可看清哪种城市空间体 现的文化是打动人心的, 是人们愿意传承下去的文 化精华。

以往对城市空间感知的研究多采用行为主义 地理学的方法(Chai et al, 2016), 它们与人文主义地 理学对城市感知的分析路径不同。行为主义地理 学对城市空间感知的分析路径是, 通过心理地图 (mental map)发掘人们对空间的感知结果。经典的 研究为, 凯文・林奇(2001)以美国波士顿、泽西城和 洛杉矶三个城市为案例地, 对居民的城市空间感知 进行调查, 其结论为: 地标、节点、道路、边界、区域 是构成居民城市空间感知的五大基本要素。该结 论的应用价值体现在: 城市管理者通过强化城市空 间的五类要素的可感知特征, 如在节点建设大型雕 塑(王爱平等, 2006), 从而增强居民对城市空间的感 知, 进而提高人们的空间行为效率, 譬如让驾车者 少迷路。国内有学者按此分析路径, 进行了类似的 城市感知研究。例如, 顾朝林等(2001)利用照片辨 认和认知地图的方法调查了北京市居民的城市意 象空间, 是以天安门为中心, 以长安街和二环、三 环、四环路等道路骨架形成的网络系统, 同时包含 了地标、结点、功能区等要素; 冯健(2005)在此基础 上进一步探讨了城市空间感知的影响因素, 认为年 龄、性别、受教育程度、经济收人、居住地等个体的 社会属性对空间感知有所影响。但上述的研究结 论并未说明分析城市空间感知所蕴含的审美向往 和道德追求。

\section{2 人文主义地理学者呈现的三类城市空间}

人文主义地理学所表达的城市空间, 是主体在 感知、知觉城市空间客体后, 赋予情感和意义的“文
本”。如果这个文本体现了人性之美, 那么这个感 知和表达的过程就达到了人文主义地理学的目标。

“我向性”的案例。中国古代营造城池考虑山 水形势。管子云: “圣人之初国者, 必于不倾之地, 而择地形之肥绕者; 乡山, 左右经水若泽” (管仲, 2009)。意思是说, 圣人建设都城, 一定在平坦稳固 的地方, 选择一块物产丰饶的土地, 北面依山, 左右 有河流或湖泽提供水源; 并建议在城内修筑与河流 连通的沟渠网络, 这样, 既利于取水, 又利于水流外 泄。人对平地、水源的本能需要, 产生了对 “宜居” 城市的空间文字表达。

“诉诸情感”的案例。明清之际, 许多在京做官 的江南人, 在什刹海的茶楼酒肆中品芳小酌时, 将 眼前的荷塘垂柳, 稻田蛙声(彼时什刹海周边还有 小片稻田), 写人了他们咏景的诗作。这些诗作中 有许多是“忆江南”的主题。京城虽是实现家国抱 负的地方，但是故乡还是心中最美的地方。这是一 种站在一个地方联想到另外一个地方的空间感知 结果。这种结果也超出了行为主义地理学的客观 感知, 这种由人性生发的空间想象, 具有积极性(周 尚意, 2016)。

“感悟性”的案例。美国当代印第安作家纳瓦 雷・斯科特・莫马迪(2013)的代表作《日诞之地》是一 个典型的例子。1950年代美国实施 “终止和重置” (Termination and Relocation)政策,终止给印第安人 保留地的优惠政策, 重置流人城市的大量印第安 人。小说中展示了两幅城市图景, 一幅体现白人将 印第安人融人主流社会的愿望, 另一幅体现印第安 人感受到的身体和精神在城市中的不适。作者用 这种反差式手法,帮助印第安人(包括作者自己)想 清楚要何种生活。小说中的一位主人公艾贝尔选 择回到祖先的故乡, 在那里获得身与心的平衡。作 者还指出,城市中的印第安人要保持与部族的精神 联系, 这可能是他们在城市中获得力量的途径(郑 佳, 2016)。这就是一种文化自觉的过程。

\section{3 人文主义地理学者对城市空间“文本”的再升华}

人文主义地理学者为何偏好对 “文本” 的研 究? 自人文主义地理学诞生到 21 世纪初, 一直有学 者质疑人文主义地理学是真正的地理学。因为有 人认为人文主义地理学的代表作都太像“文学作 品”, 或者是像文学评论, 与实践脱节。以 Tuan (1974, 1986, 1989)的著作为例, 他引经据典地道来 东西方历史或文学作品中的 “地方”, 并分析这种地 
方感背后的道德。为了将人文主义地理学变得更 像“研究”, Smith(1984)提出 “做”(do) 人文主义地理 学研究的策略框架, 其中也涉及到了文本分析的方 法。不难理解, 当人们比较两个或两个以上的“地 方(感)”时,不可能脱离文本形式的“地方”。

下面是人文主义地理学者分析城市空间文本 的案例。郑佳(2016)对《日诞之地》的分析, 是基于 文本的分析案例, 但这个案例尚未体现出郑佳对原 作者人文关怀的进一步提升。P Pocock(1981)的研究 则不同, 他一方面用经典的文学作品和绘画作品来 说明人文主义地理学如何分析文本, 如英国著名小 说家劳伦斯和艾略特的作品, 画家罗斯金和葛兰伯 的作品; 另一方面, 他在阅读中也有通过感悟的人 性提升, 例如他对《愤怒的葡萄》(约翰- 斯坦贝克, 1982)的分析。这部小说展示了作者斯坦贝克对美 国若干州的 “地方感”。作者跟随俄克拉何马州的 农民流浪到加利福尼亚, 沿途听到流浪的农民负债 累累、土地被大公司没收的故事。这些农民无家可 归, 只得西迁加利福尼亚州寻找出路。但他们走到 加利福尼亚后, 等待他们的仍然是失业、饥饿和困 苦, 那里的农场主利用过剩的劳力压低工资, 各种 地方势力又横加勒索和迫害。Pocock 在阅读这部 小说时, 感受到的是由作者建立起来的两种对立的 地方感, 进而激发起对 “乌托邦” 的憧憬。而他所憧 憬的美好之地, 并非宣传中建构的“加利福尼亚”, 这一认识过程体现了 Pocock 阅读文本过程中的“感 悟性”。主体自身也可超越自己的文本, 例如日本 作家西川满不断超越自己以前对台湾淡水的描写, 台湾学者分析了他审美经验中指涉、追寻、探究、质 问和印证的过程(蔡怡斑, 2013)。

最难的莫过于想象出美好的空间是什么样 子。有一种简单的美学创新, 可实现文本间美的超 越, 例如不同人对淡水河的描画(蔡怡玟, 2011)。但 是在道德层面上的超越就相对困难了。段义孚指 出, “人们从威胁人类的原始自然环境中逃到优雅 的文化之中, 这的确是一件好事。然而, 如果仔细 观察, 就会发现在这种优雅的表面覆盖着一层厚厚 的泡沫, 这层泡沫掩盖了严酷的经济现实和政治现 实”(段义孚, 2005)。我们在许多房地产广告中看到 “高尚社区” 的意象, 这就是一种泡沫, 它掩盖了许 多人买不起房的事实, 以及“高尚社区”对 “卑贱社 区”的轻㛊。因此有良心的地理学者将目光投向贫 富居住隔离, 致力于消除这种空间的不平等。为
此,需要人们(包括地理学者)在实践的基础上不断 提出新的规划文本, 并不断改善之。

\section{3《北京文脉》中的插图分析}

\section{1 体现“我向性”的插图案例}

图 1 展现的是北京中轴线上的钟楼和鼓楼, 以 及周边的建筑。绘图者从多个来源了解到中轴线 在古都文化中的地位。有其一是《我与中轴线》 (《我与中轴线》编委会, 2012)中许多作者的感悟, 其 二是北京正阳门博物馆的文字说明。由他者文本 帮助建构起来的空间知识是: 中轴线全长 15 华里, 15 正好是天地之和的数字。在《易经》中, 乾代表 天, 数据为九; 坤代表地, 数字为六。两者之和为十 五。这个数字的巧合并未记载在古文献中,而是后 人根据易学而推测出来的。绘图者在图 1 中,并未 展示 15 之数, 而是根据个人的生活经验, 画出了中 轴线上最美的部分一一钟鼓楼。在许多人的记忆 中, 儿时看到一些建筑往往高大宏伟, 因为当时的 身高与建筑的高度之间有一个较大的视觉高差。 绘图者从小在京长大, 他将这种儿时留下的感受展 示在图 1 中。图 1 表现出来的钟鼓楼和周边建筑的 高度差, 不是那些成人之后才到北京生活,或者到 北京旅游的人所能感受的。因而也不会体会到绘 图者心中的“钟鼓楼之雄伟”。

图 1 的“我向性”体现为绘图者将个人小时候对 中轴线上主要建筑的美好记忆呈现出来。绘图者 所经历的“文本一基于文本的感悟一超越文本的提 升”的人文主义地理学认识过程表现为: 他看了其 他人对中轴线的描写一感受到中轴线在北京城中 的重要一进而超越别人叙述的中轴线之重要,将基

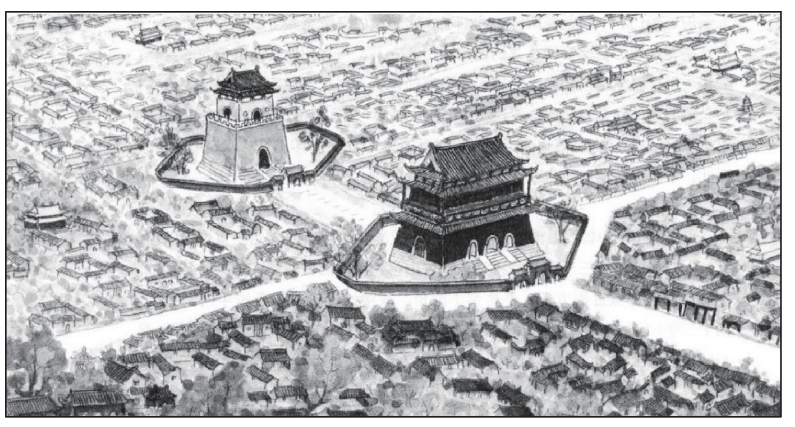

图 1 钟鼓楼与周边建筑的视觉关系(李建平, 2017)

Fig.1 Visual relation between the Drum and Bell Towers and the surroundings (Li, 2017) 
于 “我”的身体感受到的,那种中轴线之美展现给他 人共享。笔者作为图 1 的读者, 也经历着: 看图 1感受钟鼓楼和周边建筑之关系一超越这种高度之 关系, 从身体在现代城市节奏中的疲畕感受中, 升 华出对现代城市生活节奏加快、节律乱的批判, 伴 生出对“晨钟暮鼓”节律性生活的留恋。图 1 让我们 重新反思对待身体的态度。

\section{2 体现“诉诸情感”的插图案例}

图 2 呈现了皇城之内 3 个湖泊(北海、中海和南 海) 中的 3 个小岛, 由北向南, 它们依次是琼华岛、仪 天殿和屏山台。图 2 出现在书中 “人间仙境”一节 中。原书中这节并没有参考文献, 这间接说明, 绘 图者呈现的“一池三山”景观,并不是来自书写的文 本, 而是其来自其他地方生活经验建构起来的文化 空间模式。绘图者还在本节中呈现了一幅䝠和园 的“一池三山”图。“一池三山”是中国园林中的道教 文化空间营造手法。《史记》记载, 秦始皇曾派遣数 千人, 多次出海求仙问药, 但无果。他修建兰池宫, 中有一湖, 湖中三岛隐喻传说中的蓬莱、方丈、瀛洲 三神山。受此启发, 汉高祖刘邦在兴建未央宫时, 也曾在宫中开丵沧池, 池中筑岛。“一池三山”在北 京园林中非常普遍, 因此几乎成为老北京人理解园 林水景的一种习惯性 “模式”。绘图者的人生经历 证明,他并没有对仙境的喜好, 只因为是老北京人, 所以喜好这种熟悉的空间模式。

图 2 所体现的“诉诸情感” 表现为绘图者对“一 池三山”的喜爱来自对这个城市园林的熟悉,或日 常生活建构。绘图者所经历的“文本一基于文本的 感悟一超越文本的提升” 的人文主义地理学认识过

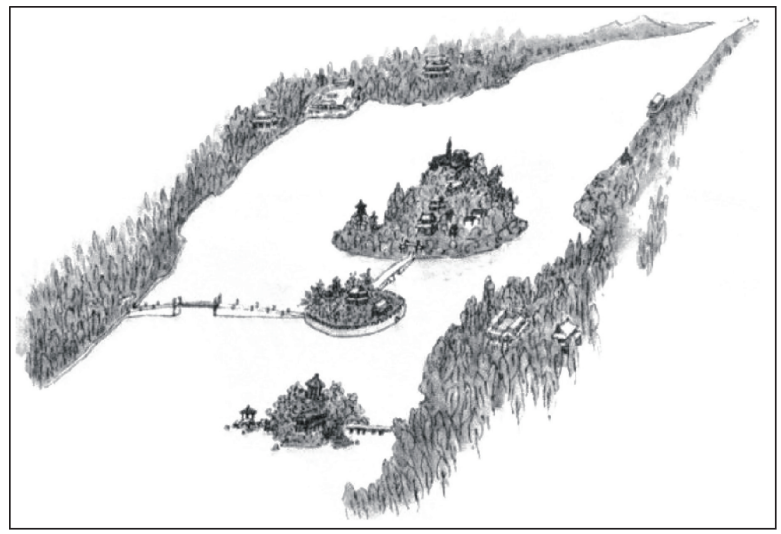

图 2 内三海一池三山的道家仙境(李建平, 2017)

Fig.2 Daoist image of "One lake with three isles" in the three Inner Lakes (Li, 2017)
程表现为:他看到建筑形式的“文本”一感悟到“一 池三山”背后的道教文化空间模式一进而超越这种 空间模式背后的道教仙境追求,联想到䝠和园中另 外一组建筑体现的佛教文化的空间秩序,再度升华 认识,即北京园林中多种宗教空间的包容性。而作 为图 2 的读者, 本文笔者也经历着: 看图 2-习得 “一池三山”的园林美学知识一超越这种习得的知 识, 发现“一池三山”模式中的差异, 例如内三海中 “仙山”与周围“凡世”的道路连接, 不同于䝠和园、 圆明园的“仙山”与 “凡世”的隔离。进而感悟到内 三海的“一池三山”, 北海的三山与湖岸相连。这种 手法给“一池三山”手法赋予新的文化空间含义 一一仙境与人间是联通的。

\section{3 体现“感悟性”的插图案例}

图 3 呈现的是天上宫阙与北京紫禁城的关联 图。绘图者的灵感有 4 个来源: 其一, 来自北京市地 方志办公室罗保平口述。罗认为古人将天象与人 间建立起密切的对应关系,例如天上玉皇大帝的凌 霄殿对应的是皇帝的紫禁城, 天上的星辰的名字对 应着城市的地名或建筑,再如天上的星辰有叫东华 门、西华门等。其二,来自首都博物馆的“大元三 都”的展览图片, 图片中将天上的紫微垣与地上的 紫禁城对应起来。其三,来自北京社科院历史研究 所王岗(2015)的《行舟集》。他认为, 大都的建造者 希望通过城市布局来体现出中国古人的宇宙观 “天人合一”的观念。大都的建造者通过把地

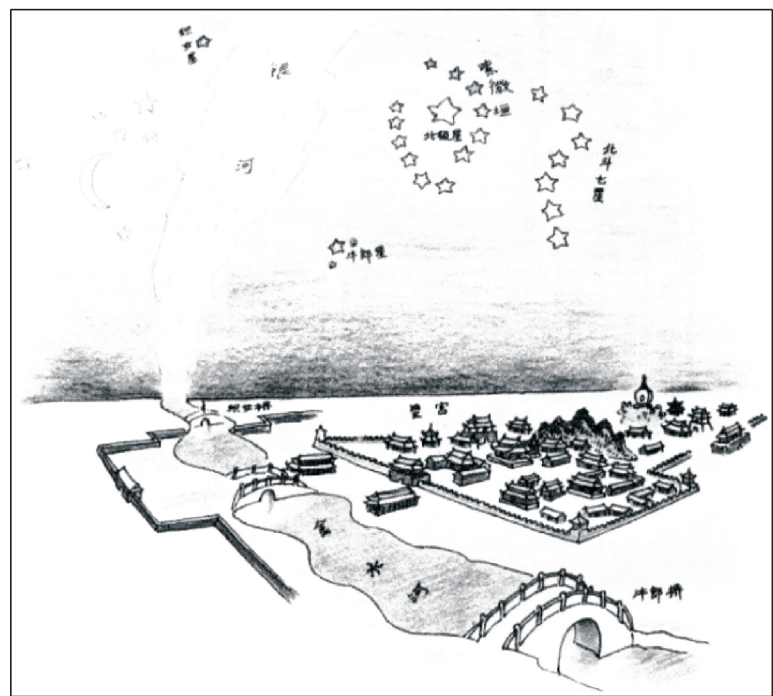

图 3 天上宫阙与紫禁城的关联图(李建平, 2017)

Fig. 3 Correspondence of the Palaces in Heaven and the Forbidden City (Li, 2017) 
上建筑物的位置与天上星辰的布局对应起来, 表现 这种“天人合一”。宫城对应天之中心紫微垣, 枢密 院在东, 对应武曲星。第四, 来源于北京西城区文 委主任孙劲松。他介绍了西城区“十三五”期间, 将 依据为清光绪年间的北京城地图, 恢复金水河及织 女桥景观, 其实这是明代的景观。织女桥东河沿胡 同就是织女桥水系的河道, 河上的织女桥与东侧的 中山公园相连通, 1990 年代, 菖蒲河公园修建, 并在 公园内重建了石拱桥即牛郎桥。绘图者将这 4 个来 源整合为图 3 , 其中包括了 4 个来源中提到的天上 星宿和地上的建筑。

绘图者的“感悟性”体现在图 3 的构图美学上。 图中流经皇城之外的金水河浔潺流向远方, 并与银 河连在一起, 天地不是两个平面, 而是天为穹隆, 下 罩大地。再也没有这么好的表现手法, 体现中国都 城文化空间格局之美感了。绘图者所经历的“文本 一基于文本的感悟一超越文本的提升”的人文主义 地理学认识过程表现为: 4 个文本来源一对 4 个来 源的整合一超越 4 个文本的美学构图。笔者作为图 3 读者, 也经历了从“看插图一感悟插图构图之视觉 美一超越这种构图之美, 扩展到思考今天城市的格 局如何体现 “天人合一”。我们基于图 3 , 再叠加上 一幅北京水系保护图, 它则体现今人 “人地和谐”的 城市空间观。

\section{4 结论与讨论}

\section{1 结论}

本文的结论有二: 一是《北京文脉》一书的插图 创作过程, 和读者藉由插图而萌生的新空间, 更多 体现了人文主义地理学的 “感悟性”。二是插图作 者和读者均经历了 “文本一基于文本的感悟一超越 文本的提升” 的认识循环, 这个过程是人性提升的 必然途径。

用人文主义地理学分析《北京文脉》, 其意义不 单是提升人性, 还可指导实践。人文主义地理学代 表学者 Ley等(1978)认为, 人文主义地理学具有将 分析结果应用到其他学科分支的策略。Daniels (1985)主张人文主义地理学在地方营造(making place)中大有可为。而本文的结论在现实中也得到 了验证, 即 2016年北京完成了对《北京城市总体规 划 2004-2020》的修编, 修编的结果虽尚未公布, 但
实际上是对原来文本的改进。我们不否认人文主 义地理学是偏思辨的(叶超, 2014), 但是思辨与实践 是很难分开的。

\section{2 讨论}

中国地理学界基本上已经普遍接受了人文主 义的这种观点, 即空间是有主体性的。人文主义地 理学的主要哲学来源之一是现象学, 现象学反对将 空间作为客体之物, 而是将人的主体认知介人空间 之中(李溪, 2014)。因此本文也非将“客观的”北京 空间作为认识的客体, 而将描写北京的文本作为认 识的客体。

实际上, 本文尚未超越 Heidegger(2009)关于 “语言与人的关系”的逻辑。海德格尔认为, 人与语 言不是主体和客体的二分结构, 语言在哪里, 人就 在哪里。文中透过《北京文脉》的语言, 尤其是手绘 地图语言, 探索了地图背后一系列的主体, 以及主 体心中的北京意象。结论一提到,书中由“感悟”形 成的北京意象比较多,而从“身体”、“感情”而生发 的北京意象比较少。通常我们比较容易理解符号 化的表征,而对于非表征的美和善还不十分敏感, 因此需要尝试从一位街道大妈或胡同里老炮儿对 北京的情感表达中,发现北京空间之美。

\section{参考文献(References)}

安宁, 钱俊希. 2017. 城市化的文学书写: 基于社会一空间辩 证法的《炸裂志》解析 [J]. 人文地理, 32(1): 47-54. [An N, Qian J X. 2017. The literary writing of China's urbanization in the post-reform era: A socio-spatial dialectical analysis on the chronicle of Zhalie[J]. Human Geography, 32 (1): 47-54.]

蔡怡玟. 2011. 以石川钦一郎、木下静涯、陈澄波、陈慧坤、李 永沦笔下之淡水作品诠释地方及其精神之意象 [J]. 地理 研究(中国台湾), (54): 43-68. [Cai Y W. 2011. An Interpretation of the tamsui place image and the spiritual image from the series tamsui paintings of Ishikawa Kinnichiro, Kinoshita Seigai, Chen Cheng-po, Chen Hui-kuen and Lee Yung- two[J]. Journal of Geographical Research(Taiwan, China), (54): 43-68.]

蔡怡玟. 2013. 那座山, 那条河: 地方及其精神之意义: 以西 川满笔下的淡水作品诠释 [J]. 鹅湖学志(中国台湾), (50): 203-241. [Cai Y W. 2013. That mountain, that river: An interpretation of place image and its spiritual meaning from the series tamsui literature works of Nishikawa mitsuzu[J]. Legein Society(Taiwan, China), (50): 203-241.] 
段义孚. 2005. 逃避主义 [M]. 周尚意, 张春梅, 译. 石家庄: 河 北教育出版社: 6. [Duan Y F. 2005. Escapism[M]. Zhou S Y, Zhang C M, Trans.. Shijiazhuang, China: Hebei Education Press: 6.]

冯健. 2005. 北京城市居民的空间感知与意象空间结构 [J]. 地理科学, 25(2): 142-154. [Feng J. 2005. Spatial cognition and the image space of Beijing's residents[J]. Scientia Geographica Sinica, 25(2): 142-154.]

顾朝林, 宋国臣. 2001. 北京城市意象空间及构成要素研究 [J]. 地理学报, 56(1): 64-74. [Gu C L, Song G C. 2001. Urban image space and main factors in Beijing $[\mathrm{J}]$. Acta Geographica Sinica, 56(1): 64-74.]

管仲. 2009. 管子 $[\mathrm{M}]$. 李山, 译. 北京: 中华书局: 313. [Guan Z. 2009. Guanzi[M]. Li S, Trans.. Beijing, China: Zhonghua Book Company: 313.]

凯文.林奇. 2001. 城市意象 [M]. 方益萍, 何晓军, 译. 北京: 华夏出版社. [Lynch K. 2001. The image of the city[M]. Fang Y P, He X J, Trans.. Beijing, China: Chinese Literature Press.]

李建平. 2017. 北京文脉 [M]. 北京: 文津出版社. [Li J P. 2017. Beijing wenmai[M]. Beijing, China: Wenchin Press.] 李蕾蕾. 2009. 从“语言转向”谈“超越”[M]//刘卫东, 柴彦威, 周尚意. 地理学评论: 第一辑. 北京: 商务印书馆. $[\mathrm{Li} \mathrm{L}$ L. 2009. Cong "yuyan zhuanxiang" tan "chaoyue"[M]//Liu W D, Chai Y W, Zhou S Y. Review in geography: Volume 1. Beijing, China: The Commercial Press.]

李溪. 2014. 段义孚人文主义地理学的哲学视野[J]. 人文地 理, 29(4): 8-12. [Li X. 2014. The philosophical perspective of Yi-Fu Tuan's humanistic geography[J]. Human Geography, 29(4): 8-12.]

莫里斯・梅洛-庞蒂. 2001. 知觉现象学 [M]. 姜志辉, 译. 北京: 商务印书馆: 140. [Merleau-Ponty M. 2001. Phénoménologie de la perception[M]. Jiang Z H, Trans.. Beijing, China: Commercial Press: 140.]

纳瓦斯科特. 莫马迪. 2013. 日诞之地 [M]. 张廷佺, 译. 南京: 译林出版社. [Scott Momaday. 2013. House made of dawn [M]. Zhang Y Q, Trans.. Nanjing: Yilin Press.]

王爱平, 周尚意, 张姝玥, 等. 2006. 关于地区性地标景观感 知和认同的研究 $[\mathrm{J}]$. 人文地理, 21(6): 124-128. [Wang A P, Zhou S Y, Zhang S Y, et al. 2006. Study on landscape perception and cognition of community landmark[J]. Human Geography, 21(6): 124-128.]

王岗. 2015. 行舟集 [M]. 北京: 北京出版社: 375-376. [Wang G. 2015. Xingzhou ji[M]. Beijing, China: Beijing Press: 375-376.]

《我与中轴线》编委会. 2012. 我与中轴线 [M]. 北京: 北京出
版社. [The Editorial Broad of Wo Yu Zhongzhouxian. 2012. Wo yu zhongzhouxian[M]. Beijing, China: Press of Beijing.]

叶超. 2014. 作为中国人文地理学鉴镜的段义孚思想 $[\mathrm{J}]$. 人

文地理, 29(4): 3-7. [Ye C. 2014. Yi-Fu Tuan's humanistic geography as a mirror of Chinese human geography[J]. Human Geography, 29(4): 3-7.]

尹铎, 钱俊希, 朱竑. 2016. 城市新区作为“家”的表征与实践: 以鄂尔多斯康巴什新区为例 [J]. 地理科学进展, 35(12): 1517-1528. [Yin D, Qian J X, Zhu H. 2016. The representation and practice of new urban district-as-home in China: A case study of Kangbashi New Town, Ordos[J]. Progress in Geography, 35(12): 1517-1528.]

约翰. 斯坦贝克. 1982. 愤怒的葡萄[M]. 胡仲持, 译. 北京: 外 国文学出版社. [Steinbeck J. 1982. The grapes of wrath [M]. Hu Z C, Trans.. Beijing, China: Foreign Literature Press.]

郑佳. 2016.《日诞之地》中的地理景观: 人文主义地理学视角 [J]. 外国文学评论, (3): 155-168. [Zheng J. 2016. Ridan zhidi zhong de dili jingguan: Renwen zhuyi dilixue shijiao [J]. Foreign Literature Review, (3): 155-168.]

周尚意. 2016. 发掘地方文献中的城市景观精神意向: 以什 刹海历史文化保护区为例 [J]. 北京社会科学, (1): 4-12. [Zhou S Y. 2016. On the spiritual images of a city from its local literatures: Take Shichahai historical district as an example[J]. Social Science of Beijing, (1): 4-12.]

周尚意, 张春梅. 2005. 从逃避主义透视人文主义地理学: 读 段义孚《逃避主义》有感 $[\mathrm{M}] / /$ 朱传耿, 沈正平, 孟召宜. 科 学发展观与人文地理学研究新进展. 北京: 科学出版社: 24-30. [Zhou S Y, Zhang C M. 2005. In perspective of humanistic geography from escaping creed: The thoughts after reading "escaping creed" written by Duan Yifu[M]// Zhu C G, Shen Z P, Meng Z Y. Kexue fazhanguan yu renwendilixue yanjiu xinjinzhan. Beijing, China: Science Press: 24-30.]

Allen C D. 2017. Humanistic geography[EB/OL]. Oxford Bibliographies. 2013-02-26 [2017-08-20]. http://www.oxfordbibliographies.com/view/document/obo- 9780199874002/ obo- 9780199874002- 0015.xml?rskey $=\mathrm{s} 04 \mathrm{v} 3 \mathrm{e} \&$ result $=$ $1 \& q=$ Humanistic + Geography\#firstMatch.

Chai Y W, Ta N, Ma J. 2016. The socio-spatial dimension of behavior analysis: Frontiers and progress in Chinese behavioral geography[J]. Journal of Geographical Sciences, 26 (8): $1243-1260$

Daniels S. 1985. Arguments for a humanistic geography[M]// Johnston R J. The Future of Geography. London, UK: 
Methuen: 143-158.

Gregory D. 2000. Humanistic geography[M]//Johnston R J, Gregory D, Pratt G, et al. The Dictionary of Human Geography. 4th ed. Malden, MA: Blackwell: 361-364.

Heidegger M. 2009. Logic as the question concerning the essence of language[M]. Gregory W T, Unna Y, Trans.. Albany, USA: State University of New York Press: 140.

Ley D, Samuels M S. 1978. Humanistic geography: Prospects and problems[M]. Chicago, USA: Maaroufa Press.

Pocock D C D. 1981. Humanistic geography and literature: Essays on the experience of place[M]. London, UK: Croom Helm.
Smith S J. 1984. Practicing humanistic geography[J]. Annals of the Association of American Geographers, 74(3): 353374.

Tuan Y F. 1974. Topophilia: A study of environmental perception, attitudes, and values[M]. New York, USA: Columbia University Press.

Tuan Y F. 1976. Humanistic geography[J]. Annals of the Association of American Geographers, 66(2): 266-276.

Tuan Y F. 1986. The good life[M]. Madison, USA: University of Wisconsin Press.

Tuan Y F. 1989. Morality and Imagination: Paradoxes of progress[M]. Madison, USA: University of Wisconsin Press.

\title{
A humanistic geographical analysis of city space: A study of three maps in Beijing's Context
}

\author{
ZHOU Shangyi ${ }^{1}$, XU Weilin', LI Jianping ${ }^{2}$ \\ (1. School of Geography, Beijing Normal University, Beijing 100875, China; \\ 2. Beijing Planning Office of Philosophy and Social Science, Beijing 100101, China)
}

\begin{abstract}
Humanistic geography is an epistemology of geography. It is characterized by its focus on self-ward thinking, affection, and consciousness. Existing studies of humanistic geography mainly discussed subjectivity of place. This study attempts to explore the humanistic features in the spiral of consciousness increment between subjects and objects. It is also a response to the opinion of Martin Heidegger-language and human are not binary oppositions. This article takes three maps in the book of Beijing's Context as examples. It compares the map illustration of the author and readers and analyzes the humanity improvement in the perceptions of Beijing's city space. The conclusions are as follows. First, the spatial cognitive process of the map drawer and readers were being conscious of the space meaning than perceiving them. Second, both the map drawer and the map readers have undergone a cognitive cycle, which is from text to text-based perception, then to thinking beyond text. This process is considered an indispensable way to improve humanity. Practically, the implication of this study is that planners should be clear about what show the progress of humanity in an updated urban planning.
\end{abstract}

Key words: humanistic geography; city of Beijing; spatial perception/cognition 